\title{
Weed Emergence in Autumn under Temperate Conditions ${ }^{1}$
}

\author{
Emergência de Plantas Daninhas no Outono em Condições Temperadas
}

\author{
CALADO, J.M.G. ${ }^{2}$, BASCH, G. ${ }^{3}$ and CARVALHO, M. ${ }^{3}$
}

\begin{abstract}
The emergence of weed plants depends on environmental conditions, especially temperature and soil moisture. The latter is extremely important in Mediterranean environments which are characterized by irregular amount and distribution of rain throughout the year, which influences the beginning of the growth cycle of the annual species (seed germination). This paper studies the influence of rainfall, in particular accumulated rainfall in autumn, on the emergence of weed plants. The experiment was carried out on Luvisols, and the appearance of flora under field conditions was observed. Through analysis of the results, it can be concluded that a high percentage of weed plants $(>85 \%$ related to the highest registered value) was obtained with more than $90 \mathrm{~mm}$ of accumulated rainfall from the beginning of September. Thus, in those years in which this amount of rainfall $(90 \mathrm{~mm})$ is registered until the end of October, the appearance of potential weed plants can be ensured, under Mediterranean conditions, in a period before sowing the autumn-winter crops.
\end{abstract}

Keywords: seasonal emergence, Mediterranean climate, rainfall, seed germination, soil moisture.

\begin{abstract}
RESUMO - A emergência de plantas daninhas depende das condições ambientais, sobretudo da temperatura e daumidade. Esta é de extrema importância em ambientes mediterrânicos, caracterizados pela irregularidade da quantidade de precipitação e da sua distribuição durante o ano, que influencia o início do ciclo vegetativo das espécies anuais (germinação de sementes). Neste trabalho, estudou-se a influência da precipitação, particularmente a quantidade acumulada no outono, na emergência de plantas daninhas. O experimento foi realizado em Luvisols, tendo sido registrado o aparecimento da flora em condições de campo. De acordo com a análise dos resultados, conclui-se que elevadas densidades populacionais de plantas daninhas (> 85\% relativamente ao valor máximo verificado) foram obtidas com uma precipitação acumulada desde o início de setembro superior a $90 \mathrm{~mm}$. Assim, nos anos em que se registra essa quantidade de precipitação até o fim de outubro $(90 \mathrm{~mm})$, garantir-se-á, em condições mediterrânicas, o aparecimento da flora potencial numa época em que pode ser controlada antes da semeadura das culturas de outono-inverno.
\end{abstract}

Palavras-chave: emergência sazonal, clima mediterrânico, precipitação, germinação de sementes, teor de humidade do solo.

\section{INTRODUCTION}

The growth cycle of annual plants, which prevail in weed flora under Mediterranean conditions begins with the germination of seeds. According to Hadas (1982), Baskin et al. (1993) and Rizzardi et al. (2009), water, from rainfall or other sources, is necessary to ensure the seeds' hydration. Seeds require sufficient water for absorption and consequent germination (Hadas, 1982; Bradbeer, 1988; Bradford, 1990; Silva et al., 2009; Yamashita $\&$ Guimarães, 2010). There are many seeds which germinate well when supplied with excess water, however in others the excess of water reduces the tegument permeability and restrains germination (Bradbeer, 1988).

Recebido para publicação em 4.5.2010 e na forma revisada em 6.5.2011.

2 University of Évora, Crop Science Department, Apartado 94, 7002-554 Évora, Portugal, Institute of Mediterranean Agricultural and Environmental Sciences (ICAAM), Apartado 94, 7002-554 Évora, Portugal, corresponding author, Phone: +351 266760822 , Fax: +351 266 760828, <jcalado@uevora.pt>; ${ }^{3}$ University of Évora, Crop Science Department, Apartado 94, $7002-554$ Évora, Portugal, Institute of Mediterranean Agricultural and Environmental Sciences (ICAAM). 
The soil's environmental conditions, such as temperature (Forcella et al., 2000; Rizzardi et al., 2009; Gardarin et al., 2010), water, air composition (oxygen, carbon dioxide, water vapour and ethylene) and the quality of light, are essential for the beginning and continuation of the growth cycle of vegetal species, particularly with regard to seed germination and emergence of plants. In the natural environment each of these factors varies based on climatic elements, such as rainfall and radiation, which can not be directly controlled by humans. Furthermore, according to Roberts (1984) and Spitters (1989), the pattern of rain distribution affects the emergence of plants which can be hampered when the superficial layer of the soil dries quickly.

In addition to rainfall, temperature is also important in the emergence of weed plants (Forcella et al., 2000; Myers et al., 2004; Rizzardi et al., 2009) as well as the moisture level of the topsoil (Gardarin et al., 2010). Thus, as a result of complex interactions, the species are able to enter into and remain in agricultural environments, and can expand in these habitats (Martinez-Ghersa et al., 2000). The environment is the sum of some living (biotic) and non-living (abiotic) factors which affect plants (Holt, 1991). The abiotic components may be divided into micro environment (near the soil) or macro environment of regional range, in other words, the environment that is felt on the soil surface (Holt, 1991).

This paper studies the influence of environmental conditions, namely those of climatic origin, such as temperature and rainfall, which are the main catalysts of plant emergence, and specially rainfall because of its influence on soil moisture and thus on the emergence of weed plants in autumn. The objective of this study was to obtain information with regard to appearance of weed plants, based on the environmental conditions of the Mediterranean autumn.

\section{MATERIALS AND METHODS}

The experiment was carried out at Revelheira farm in the Évora district of Portugal $\left(38^{\circ} 27^{\prime} 54^{\prime \prime} \mathrm{N} ; 7^{\circ} 28^{\prime} \mathrm{W}\right)$ on a Luvisol during 1996/97, 1997/98, 1998/99 and 1999/ 00 seasons in a field where winter wheat was direct drilled since 1995/96.

\section{Soil and climate conditions}

'The physical and chemical characteristics of the Luvisols were obtained through laboratory analysis of various samples of the top layer $(0-10 \mathrm{~cm})$ collected during field work. Accordingly, the top layer is a loam soil in 1996/97 and 1998/99 (36.5\% sand, 41.6\% silt and $21.9 \%$ clay) and sandy loam soil in 1997/98 and 1999/00 (68.9\% sand, 13.6\% silt and $17.5 \%$ clay), with a bulk density of 1.6 (1996/97 and 1998/99), 1.7 (1997/98 and $1999 / 00)$ and water retention characteristics which are presented in Figure 1. Relatively to some chemical characteristics the following parameters had been verified: available $\mathrm{P}$ and $\mathrm{K}$ of 10.5 ppm $\mathrm{P}_{2} \mathrm{O}_{5}$ and 69 ppm K $\mathrm{O}_{2}(1996 / 97$ and 1998/99), 20.7 ppm $\mathrm{P}_{2} \mathrm{O}_{5}$ and 64 ppm $\mathrm{K}_{2} \mathrm{O}$ (1997/98 and 1999/00); $\mathrm{pH}\left(\mathrm{H}_{2} \mathrm{O}\right) 5.8$ (1996/97 and 1998/99), 5.6 (1997/98 and 1999/00) and $1.1 \%$ (1996/97 and 1998/99), 1.2\% (1997/98 and 1999/00) of organic matter.

The values of rainfall and the average minimum, medium and maximum air temperatures observed during the four years of the experiment were registered at the Reguengos de Monsaraz weather station, located at Revelheira farm. The 30-year monthly average precipitation, was obtained through the Instituto Nacional de Meteorologia e Geofísica (1991), based on the values registered at the Reguengos de Monsaraz pluviometric station.

\section{Experimental design and analysis}

For the purposes of this study, eight plots (replicates), of one square meter each, were delimited at random, as described in sequence (Colbach et al., 2000). The one square meter plots were chosen randomly within the trial area of around $3000 \mathrm{~m}^{2}$ that was located in a field where wheat was direct drilled. No tillage operations were performed neither during the trial period nor the year before. The areas were subject to sheep grazing during the summer period until the establishment of the trials. This type of management was chosen 
to simulate the conditions of a wheat crop established in a rotation of cereals and natural pasture, commonly used under rainfed Mediterranean conditions.

The amount of weed plants and the soil moisture of the topsoil $(0-10 \mathrm{~cm}$ deep) were determined in each plot (replication). There was an interval of around ten days, between the observations, without removal of the plants. Table 1, presents a summary of the parameters observed and the methods used at different observation times (four to seven per year until stabilizing the population).

The results obtained are classified according to quantitative factors (for example plant density). According to Petersen (1977), a procedure that provides adequate information

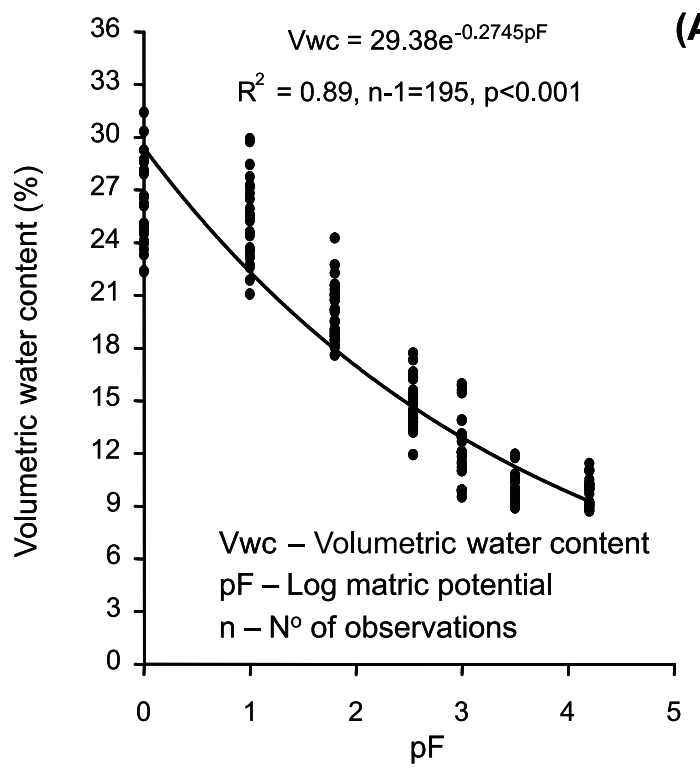

is adjustment of the response function, using regression equations. Thus, the data were related, whenever possible, using the regression equations. These equations were calculated using Statistical Package for Social Sciences (SPSS) 18.0 program.

The relations were established with either the average result of the total of plants observed per square metre, or with the ratio of the population, calculated for each year, relative to the highest average number, verified at different data readout dates, thus representing the maximum potential recorded until mid autumn. With the help the residual of sum of square and the coefficient of determination, an attempt was made to improve the applicability of different models to the obtained data (best fit).

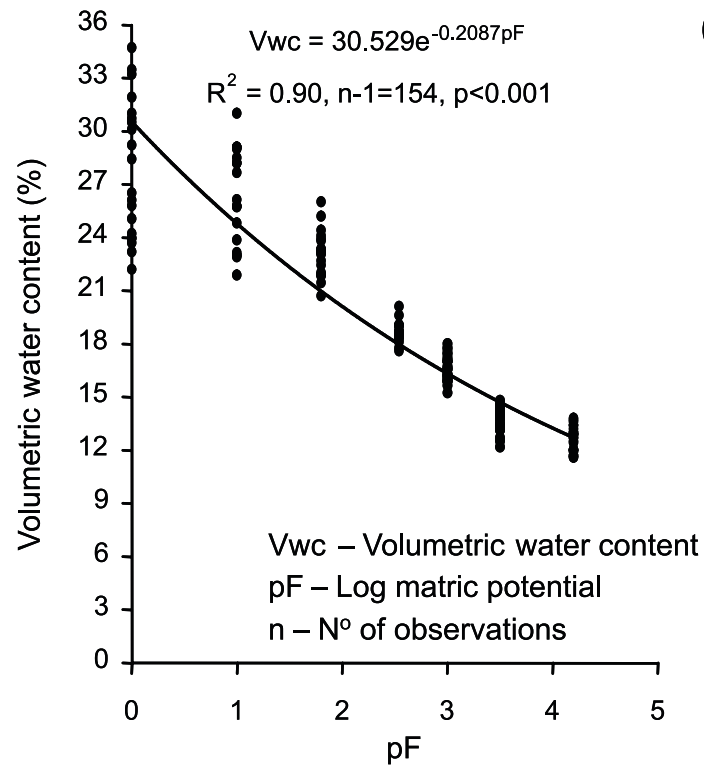

(B)

Figure 1 - Water retention curve for the topsoil (0 - $10 \mathrm{~cm}$; samples of the Luvisol collected during field work, 1996/97 and 1998/99 (A); 1997/98 and 1999/00 (B)).

Table 1 - Observed variables and the methods used

\begin{tabular}{|l|l|}
\hline \multicolumn{1}{|c|}{$\begin{array}{c}\text { Parameters refers to the coeficients (constants) of } \\
\text { mathematical equations }\end{array}$} & \multicolumn{1}{|c|}{ Method } \\
\hline $\begin{array}{l}\text { Number of weed plants; monocotyledons; dicotyledons, and } \\
\text { of some species individually (four to seven countings per } \\
\text { year) }\end{array}$ & Counting of the plants in square meter plots \\
\hline Soil moisture $(\%)$ of the topsoil $(0-10 \mathrm{~cm}$ deep) & $\begin{array}{l}\text { Values were reg istered with the TDR (Time Domain } \\
\text { Reflectometry) }\end{array}$ \\
\hline Air temperatures $\left({ }^{\circ} \mathrm{C}\right)$ and rainfall $(\mathrm{mm})$ & Daily records at the weather station of Revelheira farm \\
\hline
\end{tabular}




\section{RESULTS AND DISCUSSION}

As precipitation is determinant in the appearance of autumn-winter weed plants (Roberts, 1984; Spitters, 1989; Calado et al., 2010). It was sought to prove the influence of the accumulated rainfall on the emergence of young plants, from the beginning (September) of each of the four agricultural years of the study to the appearance of the potential population of every autumn. However, in Mediterranean climate the amount of rainfall in autumn and winter is very irregular, as can be seen in Figures 2 and 3.

(A)

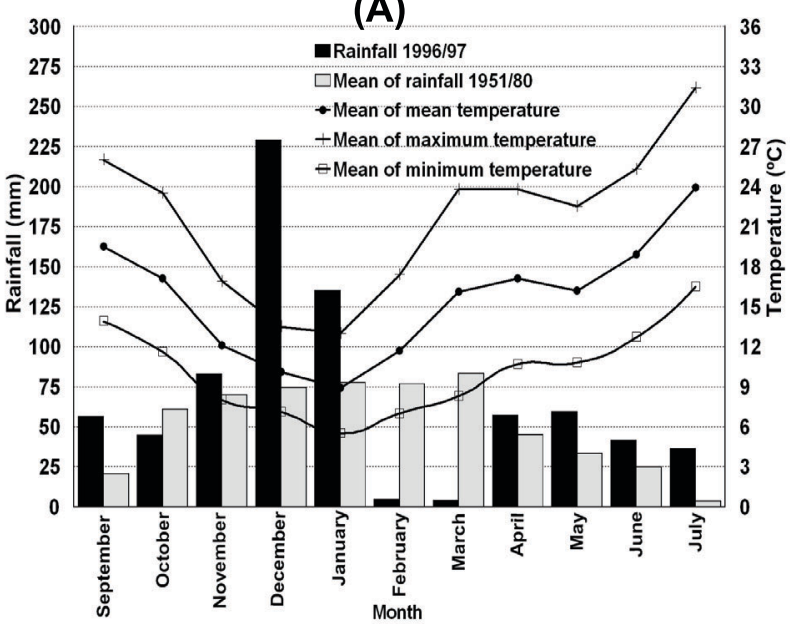

The high potential population corresponded to an accumulated amount of rainfall superior to $90 \mathrm{~mm}$ (Figure 4A), and at this rate the maximum population density was about $86 \%$ (Figure 4B). From this point on, the curve which indicates the number of plants per square metre tends to be asymptotic to the axis of abscissas. Furthermore, there can also be a population decrease, due to the mortality which characterizes the first stages after emergence of any vegetal species (Allen \& Meyer, 1998), resultant of adverse environment conditions or even interference of other plants (Bridges, 1995).

Figure 2 - Thermopluviometric conditions in 1996/97 (A) and 1997/98 (B) and the 30-year average rainfall (1951/80)

(A)

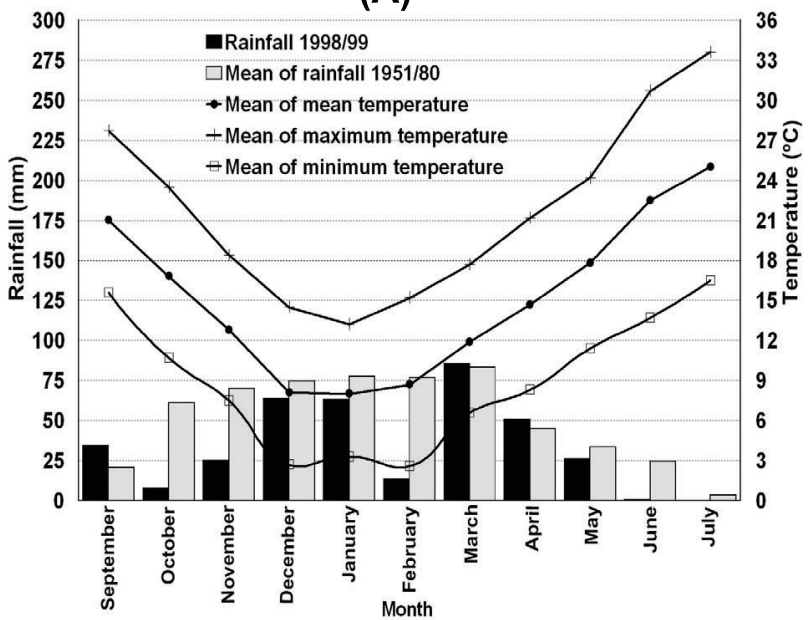

(B)

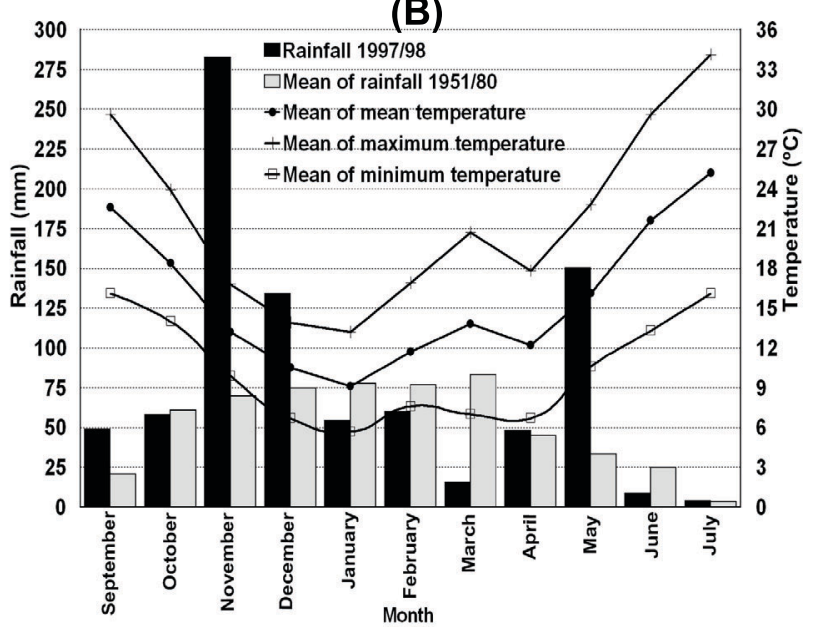

Figure 3 - Thermopluviometric conditions in 1998/99 (A) and 1999/00 (B) and the average 30-year rainfall (1951/80).

(B)

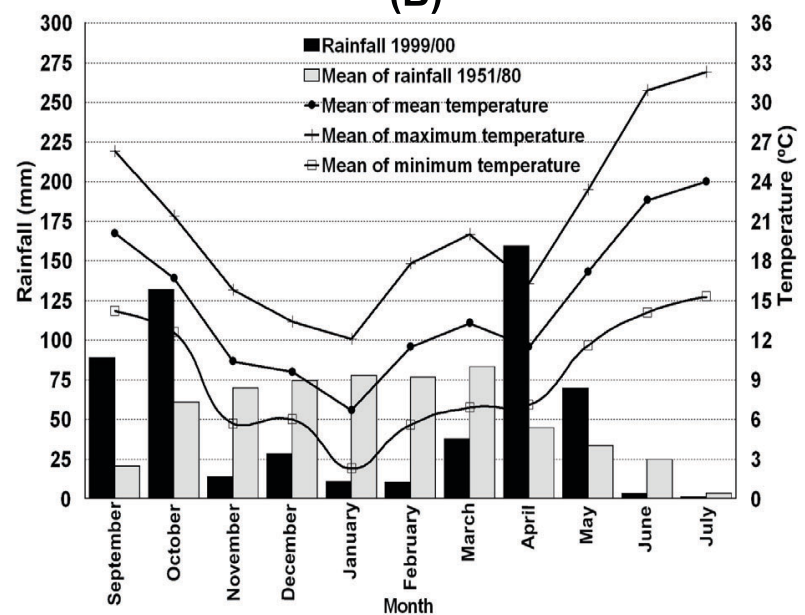



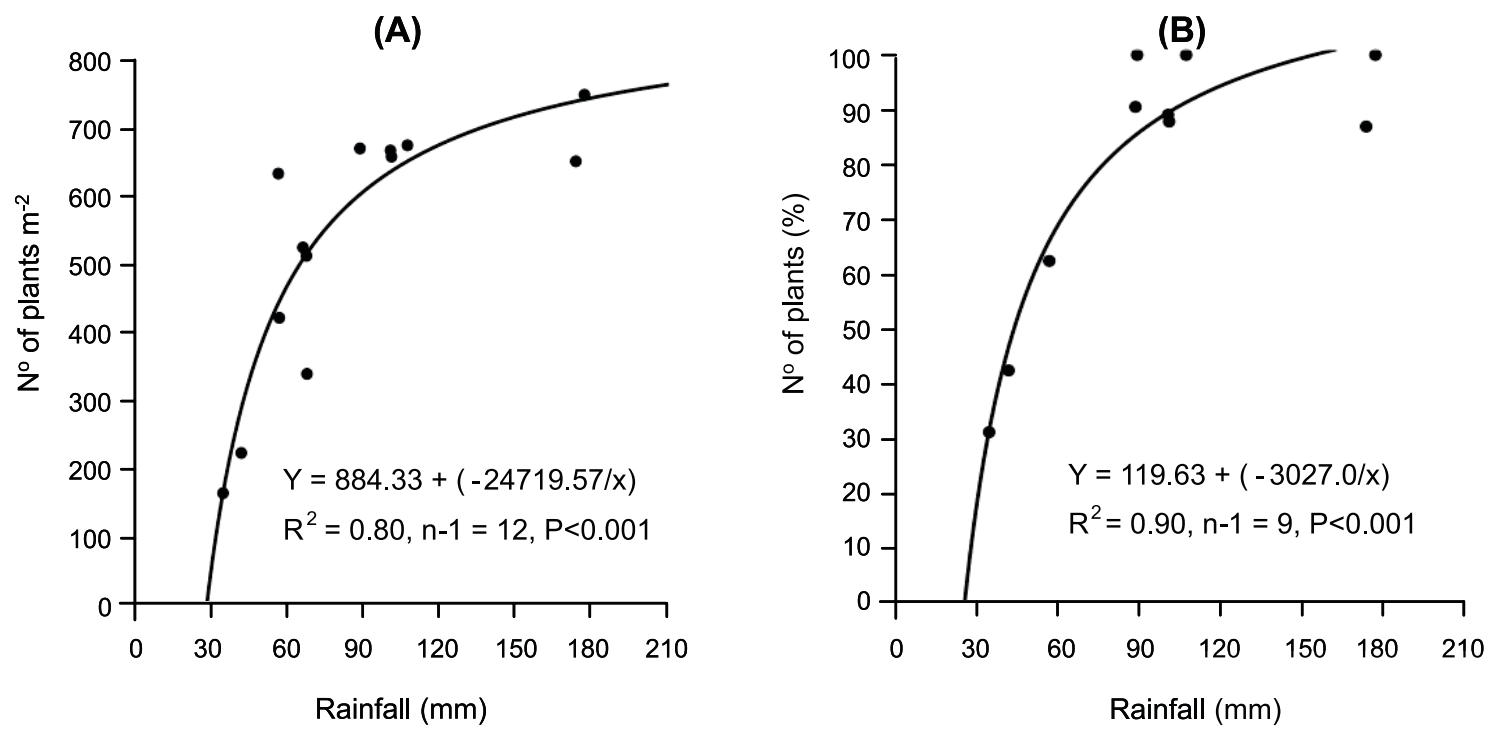

Figure 4 - Relationship between the accumulated rainfall with the number of plants (A) and the number of plants presented as percentage of the observed potential (B) (average values of the four years, 1996/97 to 1999/00).

This trend of plants total variation based on the accumulated rainfall, shown through inverse equations, is also confirmed with the number of young plants belonging to monocotyledon and dicotyledon classes with regard to the observed potential (Figure 5A, B). The highest density of monocotyledon (Figure 5A) and dicotyledon (Figure 5B) plants can also be observed with a rainfall of $90 \mathrm{~mm}$ or higher and there are no significant differences between them with regard to reaching the maximum value.

Thus, in both classes, there is a rising of population density, up to a certain extent, with increasing precipitation. In the interval of 90 to $120 \mathrm{~mm}$ rainfall there is a reduction in the populations' variation and the asymptotic trend is maintained (Figure 5).

Based on the results obtained, it can be concluded that there is a real dependence of the population density rate on temperature (Myers et al., 2004), soil moisture and the number of days since the beginning of the study, which was influenced by the first rains, in every agricultural year. So, the population density presented as percentage of the observed potential is a function of these variables in the following model [1]:

$$
\begin{aligned}
& \mathrm{Np}(\%)=-281.486+4.939 \mathrm{~h}+10.783 \mathrm{t}+2.445 \mathrm{~d} \\
& \mathrm{R}^{2}=0.77, \mathrm{~F}_{[3,13]}=14.347, \mathrm{P}<0.001
\end{aligned}
$$

Where $\mathrm{Np}$ is number of plants presented as percentage of the observed potential (\%); $h$ is volumetric soil moisture of the topsoil $(0-10 \mathrm{~cm})(\%), 14.5 \% \leq \mathrm{h} \leq 29.2 \%, \mathrm{p}<0.01$; $\mathrm{t}$ is mean air temperature $\left({ }^{\circ} \mathrm{C}\right), 13.1{ }^{\circ} \mathrm{C} \leq \mathrm{t} \leq$ $22.2{ }^{\circ} \mathrm{C}, \mathrm{p}<0.01 ; \mathrm{d}$ is the number of days since the beginning of the study, $0 \leq \mathrm{d} \leq 50, \mathrm{p}<0.01$.

According to the observations carried out during the four years (1996/97 to 1999/00), nearly one month was necessary after the first autumn rains, to obtain the maximum population density (Figure 6). In general, monocotyledons present a low rate of emergence at the beginning of the rainy season. This slow emergence rate has also been observed by Cousens (1996) for Lolium rigidum, which was the major grass weed in this field study. After the prolonged summer drought in Mediterranean environments this behaviour was confirmed for the grass weeds predominant at the study site with a share of $82 \%$ of Lolium rigidum and $17 \%$ of Phalaris L. of the monocotyledons weeds, respectively.

On the other hand, the following species prevailed in the dicotyledon class: Chamaemelum spp.; Coleostephus myconis; Echium plantagineum; Raphanus raphanistrum; Calendula arvensis; Diplotaxis catholica; Sonchus oleraceus.

Average air temperatures registered during the observation periods of the number of 

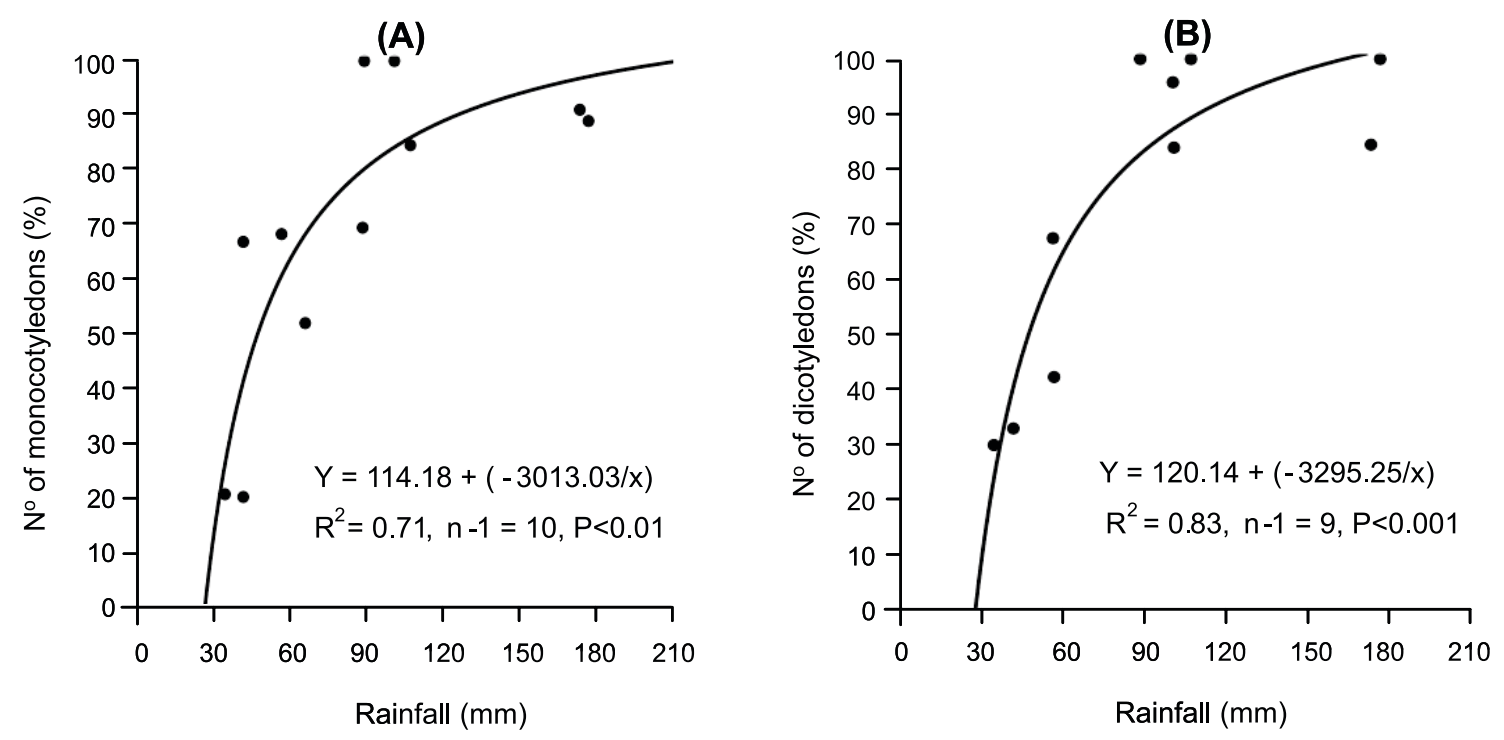

Figure 5 - Relationship of the accumulated rainfall with the number of monocotyledons (A) and dicotyledons (B) presented as percentage of the observed potential (average values of the four years, 1996/97 to 1999/00).

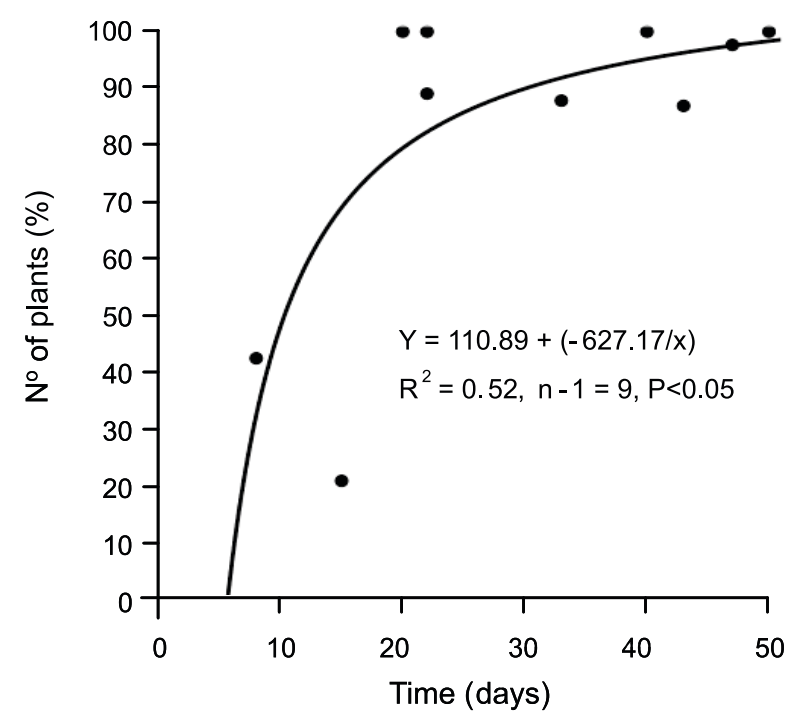

Figure 6 - Relationship between the number of days and the number of plants presented as percentage of the observed potential (average values of the four years, 1996/97 to 1999/00).

weeds emerged varied between 13.1 to $22.2{ }^{\circ} \mathrm{C}$ (with a tendency to diminish with time), which was sufficient to promote weed emergence. Considering the lowest and highest temperature limits, the mild temperature conditions are favourable to seed germination (Bradbeer, 1988; Yamashita et al., 2009).
The interaction of temperature with soil moisture (Forcella et al., 2000; Grundy \& Mead, 2000; Rizzardi et al., 2009; Gardarin et al., 2010), mainly the highest temperatures in the indicated interval of values, with the highest soil moisture, favoured plant emergence. In addition, maintenance of the average temperature between the mentioned values (mild temperature conditions) associated with soil moisture tending to field capacity, makes it possible for the potential population to appear faster, thus, according to Spitters (1989), Silva et al. (2009) and Yamashita \& Guimarães (2010) less time is necessary for obtaining a given germination percentage.

The appearance of the potential weed flora during this period (October) will allow the control of these plants before sowing the autumnwinter cereals. This pre-sowing control is particularly important in no-till systems.

On the other hand, the emergence of potential plants at the beginning of autumn is relevant for good establishment of natural pastures, which are essential for excellent production of biomass during this period.

\section{ACKNOWLEDGEMENTS}

This study was carried out with the support of the Regional Directorate of Agriculture of 
Alentejo. We thank the Directorate, as well as all those who have contributed to it.

\section{LITERATURE CITED}

ALLEN, P. S.; MEYER, S. E. Ecological aspects of seed dormancy loss. Seed Sci. Res., v. 8, n. 2, p. 183-191, 1998.

BASKIN, C. C; CHESSON, P. L.; BASKIN, J. M. Annual seed dormancy cycles in two desert winter annuals. J. Ecol., v. 81, n. 3 , p. 551-556, 1993

BRADBEER, J. W. Seed dormancy and germination Glasgow: Blackie Academic \& Professional, 1988. 146 p.

BRADFORD, K. J. A water relations analysis of seed germination rates. Plant Physiol., v. 94, n. 3, p. 840-849, 1990

BRIDGES, D. C. Handbook of Weed Management Systems. In: SMITH, A. E. (Ed.). Ecology of weeds. New York, United States of America, 1995. p. 19-34.

CALADO, J. M. G.; BASCH, G.; CARVALHO, M. Weed management in no-till winter wheat (Triticum aestivum L.) Crop Prot., v. 29, n. 1, p. 1-6, 2010.

COLBACH, N.; DESSAINT, F.; FORCELLA, F. Evaluating field-scale sampling methods for the estimation of mean plant densities of weeds. Weed Res., v. 40, n. 3, p. 411-430, 2000.

COUSENS, R. D. Comparative growth of wheat, barley, and annual ryegrass (Lolium rigidum) in monoculture and mixture Aust. J. Agric. Res., v. 47, n. 3, p. 449-464, 1996.

FORCELLA, F. et al. Modeling seedling emergence. Field Crops Res., v. 67, n. 2, p. 123-139, 2000.

GARDARIN, A. et al. Estimation of key parameters for weed population dynamics models: Base temperature and base water potential for germination. Europ. J. Agron., v. 32, n. 2, p. 162-168, 2010.

GRUNDY, A. C.; MEAD, A. Modeling weed emergence as a function of meteorological records. Weed Sci., v. 48, n. 5, p. 594-603, 2000.

HADAS, A. The Physiology and biochemistry of seed development, dormancy and germination. In: KHAN, A. A. (Ed.). Seed-soil contact and germination. Amsterdam: 1982. p. 507-527.
HOLT, J. S. Applications of physiological ecology to weed science. Weed Sci., v. 39, n. 3, p. 521-528, 1991.

INSTITUTO NACIONAL DE METEOROLOGIA E GEOFÍSICA - INMG. O clima de Portugal - normais climatológicas da região de "Alentejo e Algarve" correspondentes a 1951/80 - fascículo XLIX. Lisboa: 1991. $98 \mathrm{p}$.

MARTÍNEZ-GHERSA, M. A. et al. Adaptive traits regulating dormancy and germination of invasive species.

Plant Species Biol., v. 15, n. 2, p. 127-137, 2000.

MYERS, M. W. et al. Predicting weed emergence for eight annual species in the northeastern United States. Weed Sci., v. 52, n. 6, p. 913-919, 2004.

PETERSEN, R. G. Use and misuse of multiple comparison procedures. Agron. J., v. 69, n. 2, p. 205-208, 1977.

RIZZARDI, M. A. et al. Temperatura cardeal e potencial hídrico na germinação de sementes de corda-de-viola (Ipomoea triloba). Planta Daninha, v. 27, n. 1, p. 13-21. 2009.

ROBERTS, H. A. Crop and weed emergence patterns in relation to time of cultivation and rainfall. Ann. Appl. Biol., v. 105, n. 2 , p. $263-275,1984$.

SILVA, C. E. B. et al. Aspectos germinativos de capimcamalote (Rottboellia cochinchinensis). Planta Daninha, v. 27, n. 2 , p. $273-281,2009$

SPITTERS, C. J. T. Simulation and systems management in crop protection. In: RABBINGE, R.; WARD, S. A.; van LAAR, H. H. (Eds.). Weeds population dynamics, germination and competition. Wageningen: 1989.

p. $182-216$

YAMASHITA, O. M. et al. Fatores ambientais sobre a germinação de Emilia sonchifolia. Planta Daninha, v. 27, n. 4, p. 673-681, 2009.

YAMASHITA, O. M.; GUIMARAES, S. C. Germinação das sementes de Conyza canadensis e Conyza bonariensis em função da disponibilidade hídrica no substrato.

Planta Daninha, v. 28, n. 2, p. 309-317, 2010. 